\title{
Biological Profile of HIV-Positive Patients in Bangui, Central African Republic, in 2017
}

\author{
Yawo Tufa Nyasenu1, Alain Farra1, Brice Martial Yambiyo², Alexandre Manirakiza², \\ Fernand Didier Padou', Ferdinand Yapou' ${ }^{1}$, Pulchérie Pelembi', Rodolphe Mambely-Nzako', \\ Marie-Joëlle Mandeng1, Alain Berlioz-Arthaud'1, Pierre-Alain Rubbo', Jean-Pierre Lombart ${ }^{1}$

\begin{abstract}
${ }^{1}$ Institut Pasteur of Bangui, Medical Analysis Laboratory, Bangui, Central African Republic
${ }^{2}$ Institut Pasteur of Bangui, Epidemiology Service, Bangui, Central African Republic

Email: *nyasenu@yahoo.fr, farra_alain@yahoo.fr, ybricemartial@yahoo.fr, alexandre.manirakiza@pasteur-bangui.org, fdpadou@yahoo.fr, fyapou@yahoo.fr, pulcherima2@yahoo.fr, mambely_rodolphe@yahoo.fr, mjmandeng@yahoo.fr, alain.berlioz-arthaud@pasteur.fr, pierrealainrubbo@gmail.com, jean-pierre.lombart@pasteur.fr
\end{abstract}

How to cite this paper: Nyasenu, Y.T., Farra, A., Yambiyo, B.M., Manirakiza, A., Padou, F.D., Yapou, F., Pelembi, P., Mambely-Nzako, R., Mandeng, M.-J., Berlioz-Arthaud, A., Rubbo, P.-A. and Lombart, J.-P. (2018) Biological Profile of HIV-Positive Patients in Bangui, Central African Republic, in 2017. World Journal of AIDS, 8, 11-20.

https://doi.org/10.4236/wja.2018.81002

Received: January 13, 2018

Accepted: March 5, 2018

Published: March 8, 2018

Copyright $\odot 2018$ by authors and Scientific Research Publishing Inc. This work is licensed under the Creative Commons Attribution International License (CC BY 4.0).

http://creativecommons.org/licenses/by/4.0/

(c) (i) Open Access

\begin{abstract}
Background: The biological profile of HIV-positive patients is essential for diagnosing treatment failure and the prognosis of infection. We determined the virological and immunological profiles and biological anomalies of HIV-positive people on antiretroviral therapy (ART) in Bangui, Central African Republic. Methods: We conducted an analytical, descriptive study between 4 April and 30 September 2017 of all patients who had received ART for more than 12 months and who attended the Medical Analysis Laboratory of the Institut Pasteur in Bangui for a complete biological work-up, including viral load. A blood sample was taken for quantification of RNA HIV-1, CD4 lymphocytes and blood count in two tubes containing ethylenediamine tetraacetic acid, and another sample was taken in a dry tube for measurement of creatinine and transaminases. Results: The total population comprised 1748 patients, with a mean age of 38.7 years ( \pm 14.3 ; median, 41 years; range, 2 - 79 years); $33.3 \%$ of patients were between 40 and 49 years old. Females predominated $(71.3 \%)$, for a sex ratio of 0.4 . Immunological failure was observed in $20.2 \%$ of patients $(\mathrm{CD} 4<200$ cells $/ \mu \mathrm{L})$, and $44.5 \%$ of patients had a load of RNA HIV-1 $\geq 1000$ copies $/ \mathrm{mL}$. The main haematological anomalies were anaemia (28.0\%), leukopenia (26.7\%), neutropenia (42.1\%) and lymphopenia (27.2\%). Blood creatinine was abnormal in $61.0 \%$ of patients, ALAT in $57.0 \%$ and ASAT in $66.9 \%$. Conclusion: The abnormalities observed in this study concerned the haematopoietic system, the liver and the kidneys. As other organs and systems may be affected, periodic multidisciplinary biological and clinical follow-up is necessary for people living with HIV in order to improve their management.
\end{abstract}




\section{Keywords}

Anaemia, Biological, Abnormalities, HIV-1, Bangui

\section{Introduction}

HIV/AIDS remains a major public health problem throughout the world and particularly in sub-Saharan Africa. In 2017, UNAIDS estimated that 20.9 million people were receiving antiretroviral therapy (ART). In 2016, 6.1 million people in West and Central Africa were living with HIV, and 31,000 died of diseases associated with AIDS, whereas only 2.1 million people, $35 \%$ of those living with HIV in the region, had access to ART. Women account for $56 \%$ of people living with HIV in the region. In 2016, there were 370,000 new infections with HIV, representing a reduction of $9 \%$ since 2010, and the number of deaths from AIDS decreased by $21 \%$. Among children in West and Central Africa, there were 60,000 new cases of HIV infection in 2016, representing a decrease of 33\% since 2010 [1].

Treatment with multi-ART has prolonged survival, decreased morbidity and improved the quality of life of people living with HIV [2] [3] [4] [5]. ART, like HIV, may, however, attack various body systems and cause abnormalities in the haematopoietic system and organs such as the kidneys, the liver, the heart and muscles [6] [7] [8]. The drugs in ART may thus have undesirable, dangerous effects on patients [9] [10]. Interactions between drugs given for opportunistic and other infections (tuberculosis, hepatitis B) can have dangerous consequences [11] [12] [13]. Kobangue et al. [7] reported that anaemia was the cause of death of $75.8 \%$ of children on ART who died at the Paediatric Complex in Bangui between 2008 and 2013.

In the Central African Republic, there has been a decade of sociopolitical instability, which has resulted in population displacement and difficult access to treatment. The present study addresses the biological characteristics of patients on ART who attended the Institut Pasteur in Bangui for a free, complete biological follow-up as part of a national effort to improve their management.

\section{Patients, Material and Methods}

\subsection{Setting and Patients}

A cross-sectional descriptive study was conducted between 4 April and 30 September 2017 at the Institut Pasteur in Bangui, a recognized centre for public health, in collaboration with the International Committee of the Red Cross and Red Crescent Societies. The institute has a medical analytical laboratory, which provides biomedical analyses for the population of the country. We included all patients with HIV/AIDS who had been on ART for at least 12 months for whom systematic biological follow-up had been conducted during the study period. The inclusion criteria were the presence of HIV-1 infection, ART for at least 1 year and a complete biological work-up, which comprised plasma viral load, 
CD4 lymphocyte count, blood creatinine and transaminases and blood count. We excluded from this study: HIV-infected patients who were on treatment for less than one year, patients with incomplete biological status, and patients infected with HIV-2. In this study using clinical files and electronic registers, the patient's identity was not collected in the survey file to ensure ethical clearence.

\subsection{Sampling}

Blood samples were taken for quantification of RNA HIV-1 and for blood counts in two tubes containing ethylene diamine tetra-acetic acid (EDTA), and another was taken in a dry tube for measurement of blood creatinine and transaminases.

\subsection{Biological Analyses}

RNA-HIV was extracted with a Biocentric kit (12.08.02-170510) on a NorDiag Arrow (AO637R3) extractor. Biocentric kits (TR001-250IC) were used for RNA-HIV amplification by real-time PCRon an Applied Biosystems 7500 Fast System (4357362). The targeted region is on the long terminal repeats (LTRs), and the detection threshold was 300 copies $/ \mathrm{mL}$ in a sample of $10 \mu \mathrm{L}$. The technique is specific for HIV-1 group M, subtypes A-H. Blood creatinine with automated Jaffe colorimetric method, aspartate and alanine transaminases (ASAT and ALAT) were measured on ABX Pentra 400 (RAB1251FR). Blood creatinine was considered normal at $6-13 \mathrm{mg} / \mathrm{L}$ and ASAT and ALAT at $11-66 \mathrm{UI} / \mathrm{L}$ and 15 46 UI/L, respectively. An ABX Pentra 60 (111P6010797) from HORIBA was used for blood cell counts. Cut off for anaemia was defined as haemoglobin levels lower than $11 \mathrm{~g} / \mathrm{dL}$ in women and lower than $12 \mathrm{~g} / \mathrm{dL}$ in men.

\subsection{Statistical Analysis}

The analysis was performed on all data from included patients (exhaustive sampling). Data were entered onto an Excel ${ }^{\circledR}$ sheet and analysed with Stata software. We recorded the sex and age of our study population, the viral load, presented as $<1000$ copies/mL (virological failure) and $\geq 1000$ copies/mL (virological success), and CD4 cell counts, with immunological failure defined as $<200$ cells $/ \mathrm{mm}^{3}$ and immunological success as $\geq 200$ cells $/ \mathrm{mm}^{3}$. The World Health Organization (WHO) guidelines recommend the use of viral load as the preferred method for monitoring treatment response over clinical and immunological approaches, and define virological and immunological failure respectively with a threshold of 1000 copies $/ \mathrm{mL}$ and 200 cells $/ \mathrm{mm}^{3}$ [14] [15]. Student's $t$ test, the chi-squared test and calculation of odds ratios (ORs) with 95\% confidence intervals (CIs) were used to compare viral loads and CD4 cell counts according to biological abnormalities. The threshold for significance was set at $5 \%$.

\section{Results}

A total of 1748 patients were entered into the study, with a mean age of $38.7 \pm$ 
14.4 years and a median of 41 years (range, 2 - 79); most (33.3\%) were aged 40 49 years, and most were female $(71.3 \%)$, for a sex ratio of 0.4 .

\subsection{Characteristics of Patients}

Immunological failure was seen in $20.2 \%$ and virological failure in $44.5 \%$ of patients. Anaemia was observed in $28.0 \%$ of patients (Table 1 ).

\subsection{Biological Parameters of Patients}

Patients with immunological failure had lower mean values for haemoglobin, haematocrit, mean blood count, leukocytes, polynuclear eosinophils and basophils and lymphocytes than those with immunological success but higher values for creatinine, ALAT and ASAT (Table 2).

Patients with virological failure had lower mean values for erythrocytes, haemoglobin and mean blood count but a higher mean value for ASAT. The mean haemoglobin concentration was $12.4 \mathrm{~g} / \mathrm{dL}(10.2-12.5 \mathrm{~g} / \mathrm{dL})$ in patients with virological success and $11.6 \mathrm{~g} / \mathrm{dL}(11.4-11.7 \mathrm{~g} / \mathrm{dL})$ for those with virological failure (Table 3).

Table 1. Characteristics of patients.

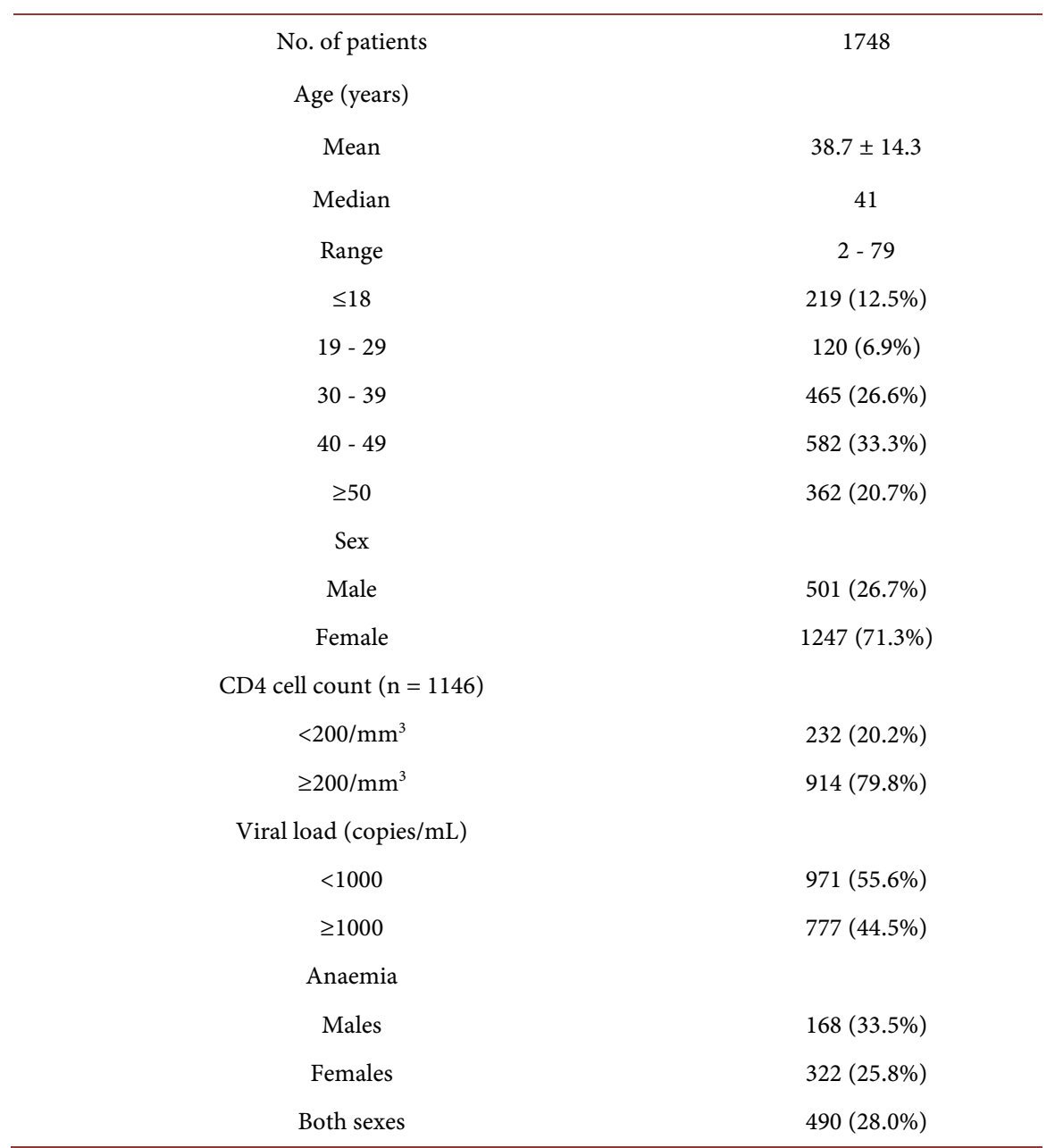


Table 2. Biological parameters of patients according to CD4 cell count.

\begin{tabular}{|c|c|c|c|c|c|}
\hline \multirow{2}{*}{ Parameter } & \multicolumn{2}{|c|}{$\mathrm{CD} 4<200 / \mathrm{mm}^{3}$} & \multicolumn{2}{|c|}{$\mathrm{CD} 4 \geq 200 / \mathrm{mm}^{3}$} & \multirow{2}{*}{ Significance } \\
\hline & No. of samples & Mean $(95 \%$ CI $)$ & No. of samples & Mean $(95 \% \mathrm{CI})$ & \\
\hline Red blood cells $\left(10^{9} / \mathrm{L}\right)$ & 232 & $3.77(3.6 ; 3.8)$ & 914 & $4.01(3.9 ; 4.0)$ & 0.001 \\
\hline Haemoglobin $(\mathrm{g} / \mathrm{dL})$ & 232 & $11.08(10.8 ; 11.3)$ & 914 & $12.27(12.1 ; 12.3)$ & 0.001 \\
\hline Haematocrit & 232 & $0.32(0.3 ; 0.3)$ & 914 & $0.45(0.3 ; 0.5)$ & 0.259 \\
\hline Mean cell volume (fL) & 232 & $86.55(85.1 ; 88.0)$ & 914 & $90.59(88.9 ; 92.3)$ & 0.023 \\
\hline Mean cell haemoglobin content (pg) & 232 & $29.68(29.1 ; 30.2)$ & 914 & $33.97(28.5 ; 39.3)$ & 0.433 \\
\hline Mean cell haemoglobin content $(\mathrm{g} / \mathrm{dL})$ & 232 & $34.22(34.0 ; 34.3)$ & 914 & $34.22(34.1 ; 34.3)$ & 0.954 \\
\hline Leukocyte count $\left(10^{6} / \mathrm{L}\right)$ & 232 & $4.71(4.3 ; 5.0)$ & 914 & $5.53(5.3 ; 5.7)$ & 0.001 \\
\hline Polynuclear neutrophils $\left(10^{6} / \mathrm{L}\right)$ & 232 & $4.28(1.1 ; 7.4)$ & 913 & $2.72(2.0 ; 3.3)$ & 0.139 \\
\hline Polynuclear eosinophils $\left(10^{6} / \mathrm{L}\right)$ & 232 & $0.22(0.1 ; 0.2)$ & 913 & $0.33(0.3 ; 0.3)$ & 0.003 \\
\hline Polynuclear basophils $\left(10^{6} / \mathrm{L}\right)$ & 232 & $0.02(0.02 ; 0.02)$ & 913 & $0.04(0.04 ; 0.05)$ & 0.001 \\
\hline Lymphocytes $\left(10^{6} / \mathrm{L}\right)$ & 231 & $1.35(1.2 ; 1.4)$ & 913 & $2.18(2.1 ; 2.2)$ & 0.001 \\
\hline Monocytes $\left(10^{6} / \mathrm{L}\right)$ & 231 & $3.72(1.2 ; 8.6)$ & 912 & $1.74(0.1 ; 3.3)$ & 0.332 \\
\hline Platelets $\left(10^{6} / \mathrm{L}\right)$ & 230 & $272.96(256.8 ; 289.0)$ & 909 & $285.55(277.2 ; 293.8)$ & 0.180 \\
\hline Blood creatinine (mg/L) & 213 & $12.11(9.9 ; 14.2)$ & 777 & $9.39(8.8 ; 9.9)$ & 0.001 \\
\hline $\operatorname{ALAT}(\mathrm{UI} / \mathrm{L})$ & 211 & $34.86(28.5 ; 41.1)$ & 782 & $28.80(27.2 ; 303.3)$ & 0.001 \\
\hline ASAT (UI/L) & 209 & $48.80(39.3 ; 58.2)$ & 782 & $32.53(30.4 ; 34.6)$ & 0.001 \\
\hline
\end{tabular}

Table 3. Biological parameters of patients according to viral load.

\begin{tabular}{|c|c|c|c|c|c|}
\hline \multirow{2}{*}{ Parameter } & \multicolumn{2}{|c|}{ Viral load $<1000$ copies $/ \mathrm{mL}$} & \multicolumn{2}{|c|}{ Viral load $\geq 1000$ copies $/ \mathrm{mL}$} & \multirow{2}{*}{ Significance } \\
\hline & No. of samples & Mean $(95 \% \mathrm{CI})$ & No. of samples & Mean $(95 \% \mathrm{CI})$ & \\
\hline Red blood cells $\left(10^{9} / \mathrm{L}\right)$ & 971 & $4.02(3.9 ; 4.0)$ & 777 & $3.88(3.8 ; 3.9)$ & 0.001 \\
\hline Haemoglobin (g/dL) & 971 & $12.38(10.2 ; 12.5)$ & 777 & $11.58(11.4 ; 11.7)$ & 0.001 \\
\hline Haematocrit & 971 & $0.58(0.3 ; 0.8)$ & 777 & $0.48(0 / 1 ; 0.7)$ & 0.572 \\
\hline Mean cell volume (fL) & 971 & $91.39(89.7 ; 93.0)$ & 777 & $87.96(87.1 ; 88.7)$ & 0.001 \\
\hline Mean cell haemoglobin content (pg) & 971 & $31.76(31.1 ; 32.2)$ & 777 & $33.47(27.1 ; 39.8)$ & 0.554 \\
\hline Mean cell haemoglobin content $(\mathrm{g} / \mathrm{dL})$ & 971 & $34.37(34.2 ; 34.3)$ & 777 & $34.10(33.9 ; 34.2)$ & 0.002 \\
\hline Leukocyte count $\left(10^{6} / \mathrm{L}\right)$ & 971 & $5.27(5.1 ; 5.4)$ & 777 & $5.43(5.2 ; 5.6)$ & 0.199 \\
\hline Polynuclear neutrophils $\left(10^{6} / \mathrm{L}\right)$ & 970 & $2.95(1.9 ; 3.9)$ & 777 & $2.48(2.3 ; 2.6)$ & 0.397 \\
\hline Polynuclear eosinophils $\left(10^{6} / \mathrm{L}\right)$ & 969 & $0.33(0.30 ; 0.36)$ & 777 & $0.30(0.27 ; 0.33)$ & 0.199 \\
\hline Polynuclear basophils $\left(10^{6} / \mathrm{L}\right)$ & 969 & $0.04(0.03 ; 0.05)$ & 777 & $0.04(0.04 ; 0.05)$ & 0.698 \\
\hline Lymphocytes $\left(10^{6} / \mathrm{L}\right)$ & 968 & $2.07(2.0 ; 2.1)$ & 777 & $4.42(0.2 ; 0.9)$ & 0.270 \\
\hline Monocytes $\left(10^{6} / \mathrm{L}\right)$ & 968 & $2.86(0.8 ; 4.9)$ & 776 & $1.77(0.1 ; 3.3)$ & 0.426 \\
\hline Platelets $\left(10^{6} / \mathrm{L}\right)$ & 966 & $278.99(271.1 ; 286.8)$ & 773 & $283.53(275.3 ; 291.7)$ & 0.436 \\
\hline Blood creatinine (mg/L) & 575 & $9.67(9.0 ; 10.2)$ & 564 & $10.02(9.1 ; 10.9)$ & 0.530 \\
\hline $\operatorname{ALAT}(\mathrm{UI} / \mathrm{L})$ & 584 & $29.22(27.5 ; 30.9)$ & 567 & $30.00(27.2 ; 32.7)$ & 0.631 \\
\hline ASAT (UI/L) & 583 & $30.66(29.2 ; 32.1)$ & 565 & $39.88(35.5 ; 44.2)$ & 0.001 \\
\hline
\end{tabular}




\subsection{Biological Anomalies}

The biological anomalies observed are shown in Table 4 and Table 5.

Patients with immunological success were more likely to have anaemia $(65.4 \%$ of females and 59.3\% of males), leukopenia (66.6\%), eosinophilia (85.8\%), lymphopenia (56.3\%), thrombopenia (65.0\%), microcytosis (69.7\%), hypochromia (72.0\%) and abnormal ASAT (74.8\%). Of patients with a high viral load, $36.9 \%$ had anaemia, 51.6\% had leukopenia, $46.0 \%$ had neutropenia, and $52.6 \%$ had lymphopenia. Blood creatinine was abnormal in $37.4 \%$ of patients with a high viral load, and abnormal ALAT and ASAT were found in $36.4 \%$ and $41.2 \%$ of these patients (Table 5).

\section{Discussion}

Our finding of a sex ratio of 0.4 and a median age of 41 years are similar to those of Mouala et al. [13], who also found a sex ratio of 0.4 and a median age of 32.5 years among HIV-positive patients in Bangui, and of Loua et al. [16], who reported a sex ratio of 0.5 and a median age of 40 years in a study in Conakry, Guinea. Mouhari-Touré et al. [17] reported a predominance of women (68.6\%)

Table 4. Biological anomalies according to CD4 cell count.

\begin{tabular}{|c|c|c|c|c|c|}
\hline Anomaly & No. of samples (\%) & $\mathrm{CD} 4<200 / \mathrm{mm}^{3}$ (No. $\left.(\%)\right)$ & $\mathrm{CD} 4 \geq 200 / \mathrm{mm}^{3}$ (No. (\%)) & Odds ratio $(95 \% \mathrm{CI})$ & $P$ \\
\hline \multicolumn{6}{|l|}{ Anaemia } \\
\hline Females $<11 \mathrm{~g} / \mathrm{dL}$ & $208(16.7)$ & $72(34.6)$ & $136(65.4)$ & $3.07(2.1 ; 4.3)$ & 0.001 \\
\hline Males $<12 \mathrm{~g} / \mathrm{dL}$ & $113(22.6)$ & $46(40.7)$ & $67(59.3)$ & $4.58(2.9 ; 7.1)$ & 0.001 \\
\hline Leukopenia $\left(<4 \times 10^{6} / \mathrm{L}\right)$ & $308(26.9)$ & $103(33.4)$ & $205(66.6)$ & $2.74(2.0 ; 3.7)$ & 0.001 \\
\hline Leukocytosis $\left(>10 \times 10^{6} / \mathrm{L}\right)$ & $49(4.3)$ & $7(14.3)$ & $42(85.7)$ & & \\
\hline Neutropenia $\left(<1.8 \times 10^{6} / \mathrm{L}\right)$ & $468(40.8)$ & $97(20.7)$ & $371(79.3)$ & & \\
\hline Neutrophil polynucleosis $\left(<7 \times 10^{6} / \mathrm{L}\right)$ & $30(2.6)$ & $8(26.7)$ & $22(73.3)$ & & \\
\hline Eosinophilia $\left(>0.5 \times 10^{6} / \mathrm{L}\right)$ & $183(16.0)$ & $26(14.2)$ & $157(85.8)$ & $0.6(0.3 ; 0.9$ & 0.028 \\
\hline Basophilia $\left(>0.4 \times 10^{6} / \mathrm{L}\right)$ & $3(0.3)$ & 0 & $3(100)$ & & \\
\hline Lymphopenia $\left(<1.5 \times 10^{6} / \mathrm{L}\right)$ & $334(29.2)$ & $146(43.7)$ & $188(56.3)$ & $6.2(4.5-8.5)$ & 0.001 \\
\hline Lymphocytosis $\left(>0.4 \times 10^{6} / \mathrm{L}\right)$ & $39(3.4)$ & 0 & $39(100)$ & & \\
\hline Monocytosis $\left(>0.6 \times 10^{6} / \mathrm{L}\right)$ & $285(24.9)$ & $51(17.9)$ & $234(82.1)$ & & \\
\hline Thrombopenia $\left(<150 \times 10^{6} / \mathrm{L}\right)$ & $83(7.3)$ & $29(34.9)$ & $54(65.0)$ & $2.3(1.4 ; 3.8)$ & 0.001 \\
\hline Thrombocytosis $\left(>400 \times 10^{6} / \mathrm{L}\right)$ & $133(11.7)$ & $31(23.3)$ & $102(76.7)$ & & \\
\hline Microcytosis $(<80 \mathrm{fL})$ & $195(17.0)$ & $59(30.3)$ & $136(69.7)$ & $1.8(1.2 ; 2.5)$ & 0.001 \\
\hline Macrocytosis (>100 fL) & $176(15.4)$ & $23(13.1)$ & $153(86.9)$ & & \\
\hline Hypochromia (<27 pg) & $168(14.7)$ & $47(28.0)$ & $121(72.0)$ & $1,6(1,1 ; 2.4)$ & 0.007 \\
\hline Blood creatinine $>13 \mathrm{mg} / \mathrm{L}$ & $238(20.8)$ & $49(20.6)$ & $189(79.4)$ & & \\
\hline ALAT $>66 \mathrm{UI} / \mathrm{L}$ & $205(17.9)$ & $34(16.7)$ & $171(83.4)$ & & \\
\hline $\mathrm{ASAT}>46 \mathrm{UI} / \mathrm{L}$ & $301(26.3)$ & $76(25.3)$ & $225(74.8)$ & $1.4(1.0 ; 2.0)$ & 0.012 \\
\hline
\end{tabular}


Table 5. Biological anomalies according to viral load.

\begin{tabular}{|c|c|c|c|c|c|}
\hline Anomaly & No. of samples (\%) & Viral load $<1000$ copies $/ \mathrm{mL}$ & Viral load $\geq 1000$ copies $/ \mathrm{mL}$ & Odds ratio $(95 \% \mathrm{CI})$ & $P$ \\
\hline \multicolumn{6}{|l|}{ Anaemia } \\
\hline Females $<11 \mathrm{~g} / \mathrm{dL}$ & $322(25.8)$ & $186(57.8)$ & $136(42.2)$ & $2.11(1.6 ; 2.7)$ & 0.001 \\
\hline Males $<12 \mathrm{~g} / \mathrm{dL}$ & $168(33.5)$ & $115(68.5)$ & $53(31.6)$ & $3.91(2.7 ; 5.5)$ & 0.001 \\
\hline Leukopenia $\left(<4 \times 10^{6} / \mathrm{L}\right)$ & $467(26.7)$ & $226(48.4)$ & $241(51.6)$ & $1.55(1.2 ; 1.9)$ & \\
\hline Leukocytosis $\left(>10 \times 10^{6} / \mathrm{L}\right)$ & $69(3.9)$ & $7(14.3)$ & $42(85.7)$ & $2.41(0.1 ; 3.9)$ & 0.001 \\
\hline Neutropenia $\left(<1.8 \times 10^{6} / \mathrm{L}\right)$ & $735(42.1)$ & $397(54.0)$ & $338(46.0)$ & & \\
\hline Neutrophil polynucleosis $\left(<7 \times 10^{6} / \mathrm{L}\right)$ & $34(1.9)$ & $11(32.4)$ & $23(67.7)$ & $2.8(1.3 ; 5.8)$ & 0.005 \\
\hline Eosinophilia $\left(>0.5 \times 10^{6} / \mathrm{L}\right)$ & $294(16.8)$ & $168(57.1)$ & $126(42.9)$ & & \\
\hline Basophilia $\left(>0.4 \times 10^{6} / \mathrm{L}\right)$ & $8(0.45)$ & $4(50)$ & $50(0.7)$ & & \\
\hline Lymphopenia $\left(<1.5 \times 10^{6} / \mathrm{L}\right)$ & $475(27.2)$ & $225(47.4)$ & $250(52.6)$ & $1.6(1.3 ; 2.0)$ & 0.001 \\
\hline Lymphocytosis $\left(>0.4 \times 10^{6} / \mathrm{L}\right)$ & $64(3.7)$ & $25(36.2)$ & $39(60.4)$ & $2.2(1.3 ; 3.8)$ & 0.002 \\
\hline Monocytosis $\left(>0.6 \times 10^{6} / \mathrm{L}\right)$ & $440(25.2)$ & $211(48.0)$ & $229(52.1)$ & $1.6(1.3 ; 2.2)$ & 0.001 \\
\hline Thrombopenia $\left(<150 \times 10^{6} / \mathrm{L}\right)$ & $128(7.4)$ & $63(49.2)$ & $65(50.8)$ & & \\
\hline Thrombocytosis $\left(>400 \times 10^{6} / \mathrm{L}\right)$ & $202(11.6)$ & $90(44.6)$ & $112(55.5)$ & $1.6(1.2 ; 2.2)$ & 0.001 \\
\hline Microcytosis (<80 fL) & $294(16.8)$ & $131(44.6)$ & $163(55.4)$ & $1.5(1.1 ; 1.9)$ & 0.001 \\
\hline Macrocytosis (>100 fL) & $289(16.5)$ & $195(67.5)$ & $94(32.5)$ & $0.5(0.4 ; 0.7)$ & \\
\hline Hypochromia $(<27$ pg) & $252(14.4)$ & $114(45.2)$ & $138(54.8)$ & $1.6(1.2 ; 2.1)$ & 0.001 \\
\hline Blood creatinine $>13 \mathrm{mg} / \mathrm{L}$ & $695(61.0)$ & $435(65.6)$ & $260(37.4)$ & $0.6(0.5 ; 0.7)$ & 0.001 \\
\hline ALAT $>66 \mathrm{UI} / \mathrm{L}$ & $656(57.0)$ & $417(63.6)$ & $239(36.4)$ & $0.5(0.4 ; 0.7)$ & 0.001 \\
\hline ASAT $>46 \mathrm{UI} / \mathrm{L}$ & $768(66.9)$ & $452(58.9)$ & $316(41.2)$ & $0.7(0.6 ; 0.9)$ & 0.014 \\
\hline
\end{tabular}

in a study in Togo. These findings indicate that HIV infection is a problem mainly among young, sexually active women. UNAIDS reported in 2016 that women represented $56 \%$ of all people living with HIV in West and central Africa [1].

In our study, $79.8 \%$ of patients had a CD4 count $\geq 200 / \mathrm{mm}^{3}$, and $44.5 \%$ had a viral load of $<1000$ copies/mL. Lozès et al. [18] found that, after 12 months of treatment, $83.0 \%$ of patients had an undetectable viral load and $86.0 \%$ had recovered their immunocompetence. Our immunological result is therefore similar, but a high viral load persisted.

Haematological anomalies in patients on ART are the result of both immunodeficiency and dysregulation of the immune system. Anaemia was observed in $28.0 \%$ of patients in our study. This was the principal haematological anomaly found in other studies of people living with HIV: in 75.8\% in Bangui [16], 95.2\% in Zimbabwe [7], 54.5\% in Conakry [17] and $13.8 \%$ in Togo [19]. We found lower mean values for haemoglobin, haematocrit, mean cell count, leukocytes, polynuclear eosinophils and basophils and lymphocytes but higher blood creatinine, ALAT and ASAT values among patients with a low CD4 count. Immunological failure may be due to complications of opportunistic bacterial, viral, pa- 
rasitic or fungal infections or to the direct effect of the virus on certain haematopoietic progenitors, giving rise to anomalies in all cell lines [20]. Multiple ART and their secondary effects on patients' organ systems may be responsible for renal and hepatic lesions [21].

Patients with virological failure had lower mean values for erythrocytes, haemoglobin and mean blood count but a higher mean value for ASAT. The mean haemoglobin concentration was $12.4 \mathrm{~g} / \mathrm{dL}$ for patients with a low viral load and $11.6 \mathrm{~g} / \mathrm{dL}$ for those with virological failure. Nacoulma et al. [22] found a haemoglobin level of $12.2 \mathrm{~g} / \mathrm{dL}$ in a study in Burkina Faso. Such anomalies are due to the various mechanisms of HIV infection, which lead to lesions in different cells and organs. Immunological and virological failure evolves to therapeutic failure when patients are exposed to drugs that are toxic to cells.

Patients with a high CD4 cell count were more likely to have anaemia, leukopenia, eosinophilia, lymphopenia, thrombopenia, microcytosis, hypochromia and abnormal ASAT. These anomalies may be due to various inflammatory mechanisms of HIV infection and secondary effects of ART and of treatments for opportunistic infections. Beuzit et al. [8] found rates of $74 \%$ for anaemia, $20 \%$ for neutropenia and $15 \%$ for thrombopenia in central Africa, and Erhabor et al. [23] found rates of $80 \%, 24 \%$ and $10 \%$, respectively, in Nigeria. The high frequency of anaemia in these two studies was measured before initiation of treatment.

Creatinine was abnormal in $61.0 \%$ of our patients, and the transaminases ALAT and ASAT were abnormal in $57.0 \%$ and $66.9 \%$ of patients, respectively. These results corroborate those of Mouhari-Touré et al. in Togo, who found elevated ASAT in $55.9 \%$ of patients and elevated ALAT in $29.8 \%$, with a mean creatinine level of $9.6 \pm 5 \mathrm{mg} / \mathrm{L}$. HIV infection, its treatment and the associated opportunistic infections are all chronic conditions, with harmful effects on stromal, haematopoietic, hepatic and renal cells and the organism's defence mechanisms.

Patients with a high viral load were more likely to have leukopenia, leukocytosis, polynuclear neutrophilia, lymphocytosis, monocytosis, thrombocytosis and hypochromia and less likely to have anaemia and abnormal blood creatinine, ALAT and ASAT. These biological abnormalities are due to the immunodeficiency induced by HIV and also to complications of treatment, opportunistic infections and side-effects of ART.

\section{Conclusions}

We found immunological failure in $20.2 \%$ of patients and virological failure in $44.5 \%$. The main haematological anomalies observed were anaemia, leukopenia, neutropenia and lymphopenia. Blood creatinine was abnormal in $61 \%$ of patients, and liver transaminase levels were high. Biological profiling is essential for the diagnosis of therapeutic failure and for the prognosis of HIV infection. The anomalies observed in this study mainly affected the haematopoietic system, 
the liver and the kidneys. As other organs and systems may also be affected, people living with HIV should undergo periodic multidisciplinary clinical and biological follow-up in order to improve their management.

\section{Strengths and Limitations}

Since the recent introduction of HIV-1 viral load measurement in CAR, this study is the first to describe the complete biological profile of Central-African patients infected with HIV. The virological, immunological and haematological parameters were studied as well as liver and renal functions. Anemia was the most frequent abnormality described, as reported in other studies [7] [8] [20] [21] [22]. The limitation of the study concerns the poor access to laboratory facilities in the provinces. Since the Pasteur Institute is located in Bangui, most of the patients included come from the capital city. We recommend national policies together with International support will be able to implement the follow-up of HIV infected patients in the provinces.

\section{References}

[1] UNAIDS (2017) Fact sheet World AIDS Day. UNAIDS, Geneva, 1-8. http://www.unaids.org/sites/default/files/media_asset/UNAIDS_FactSheet_en.pdf

[2] Centers for Disease Control and Prevention. (1993) Revised Classification System for HIV Infection and Expanded Surveillance Case Definition for AIDS among Adolescents and Adults. Morbidity and Mortality Weekly Report, 41, 1-19.

[3] Chêne, G., Binquet, C., Moreau, J.F., Neau, D., Pellegrin, L., Malvy, D., et al. (1998) Change in CD4+ Cell Count and the Risk of Opportunistic Infection or Death after Highly Active Antiretroviral Treatment. AIDS, 12, 2313-2320. https://doi.org/10.1097/00002030-199817000-00013

[4] Hammer, S.M., Squires, K.E., Hugues, M.D., Grimes, J.M., Demeter, L.M., Currier, J.S., et al. (1997) A Controlled Trial of Two Nucleoside Analogues plus Indinavir in Persons with Human Immunodeficiency Virus Infection and CD4 Cell Counts of 200 per Cubic Millimeter or Less. The New England Journal of Medicine, 337, 725-733. https://doi.org/10.1056/NEJM199709113371101

[5] Ba-Fall, K., Gueye, P.M., Lefevre, N., Fall, I.S., Said Ali Saindou, N., et al. (2004) Evolution of Antiretroviral Treatment of HIV/AIDS Infection at Dakar Main Hospital. Médecine Tropicale, 64, 292-293.

[6] Montagnier, L. (1998) AIDS and HIV Infection. Flammarion, Paris.

[7] Kobangue, L., Gody, J.C., Diemer, S.C.H., Biguene-Sapoua-Boka, Y., Dibere Kamba, G.D. and Bobossy Serengbe, G. (2016) Epidemiological, Clinical, Biological and Therapeutic Aspects of Children Dying on Antiretrovirals at the Bangui Pediatric Complex, Central African Republic. Revue de CAMES Science de Santé, 4, 15-18.

[8] Beuzit, Y., Bougarel, J. and Ngouonimba, J. (1992) Peripheral and Medullary Hematologic Changes in HIV Infection in Central Africa. Médecine Tropicale, 52, 193-199.

[9] Aceti, A., Pasquazzi, C., Zechini, B., De Bac, C., Liverhaart Group. (2002) Hepatotoxicity Development during Antiretroviral Therapy Containing Protease Inhibitors in Patients with HIV. The Role of Hepatitis B and C Virus Infection. Journal of AIDS, 29, 41-48. https://doi.org/10.1097/00042560-200201010-00005 
[10] Carr, A. and Cooper, D.A. (2000) Adverse Effects of Antiretroviral Therapy. Lancet, 356, 1423-1430. https://doi.org/10.1016/S0140-6736(00)02854-3

[11] Malaty, L. and Kuper, J. (1999) Drug Interactions of HIV Protease Inhibitors. Drug Safety, 20, 147-169. https://doi.org/10.2165/00002018-199920020-00005

[12] Savès, M., Vandentorren, S., Daucourt, V., Marimoutou, C., Dupon, M., Couzigou, P., et al. (1999) Severe Hepatic Cytolysis: Incidence and Risk Factors in Patients Treated by Antiretroviral Combinations. Aquitaine Cohort, France, 1996-1998. AIDS, 13, 115-121. https://doi.org/10.1097/00002030-199912030-00002

[13] Mouala, C., Kaba-Mebri, J., Wata, J.B. and Rey, J.L. (2006) Factors Associated with Good Adherence in HIV-Infected Patients in Bangui. Cah Etudes Rech Francophones Santé, 16, 119-130.

[14] WHO (2016) Consolidated Guidelines on the Use of Antiretroviral Drugs for Treating and Preventing HIV Infection: Recommendations for a Public Health Approach. 2nd Edition, WHO, Geneva.

[15] WHO (2013) Consolidated Guidelines on the Use of Antiretroviral Drugs for Treating and Preventing HIV Infection: Recommendations for a Public Health Approach. WHO, Geneva.

[16] Loua, A., Dramou, C.D., Haba, N.Y., Magassouba, F.B., Lamah, M., Camara, A., Cissé, M., et al. (2011) Hematologic Profile of HIV-Infected Patients in Conakry. Hématologie, 17, 365-369.

[17] Mouhari-Touré, A., Patassi, A., Nabroulala, K.T., Djadou, K.E., Edou, K., Nyametso, D., et al. (2011) Biological Profile of Adult HIV-Infected Patients at Initiation of Treatment in Togo. Medecine Et Maladies Infectieuses, 41, 229-234. https://doi.org/10.1016/j.medmal.2010.11.007

[18] Lozès, E., Ahoussinou, C., Agassounou-Tchibozo Djikpo, M., Dahouegnon, E., Ahossouhe, N., Acoty, A. and de Souza, C. (2012) Variability of CD4 Cell Count and Viral Load in People Living with HIV on Antiretroviral Treatment: Case of Saint Jean De Dieu Hospital in Tanguieta (Benin). International Journal of Biological and Chemical Sciences, 6, 650-656.

[19] Malyangu, E., Abayomi, E.A., Adewuyi, J. and Coutts, A.M. (2000) AIDS Is Now the Commonest Clinical Condition Associated with Multilineage Blood Cytopenia in a Central Referral Hospital in Zimbabwe. Central African Journal of Medicine, 46, 59-61. https://doi.org/10.4314/cajm.v46i3.8525

[20] Bain, B.J. (1997) The Haematological Features of HIV Infection. British Journal of Haematology, 99, 1-8. https://doi.org/10.1046/j.1365-2141.1997.2943111.x

[21] Coso, D. and Gastaut, J.A. (2005) Non-Tumor Hematological Abnormalities during HIV Infection. In: Sebahoun, G., Ed., Hématologie clinique et biologique, 2nd Edition, Editions Arnette, Paris, 319-322.

[22] Nacoulma, E.W.C., Some, Y., Tieno, H., Diallo, I., Zoungrana, A., Bougnounou, R., Ouédraogo, C., et al. (2007) Evolution of Hematologic Parameters during Antiretroviral Therapy in HIV-Infected Patients in Burkina Faso. Bulletin De La Societe De Pathologie Exotique, 100, 271-274.

[23] Erhabor, O., Ejele, O.A., Nwauche, C.A. and Buseri, F.I. (2005) Some Haematological Parameters in Human Immunodeficiency Virus (HIV) Infected Africans: The Nigerian Perspective. Nigerian Journal of Medicine, 14, 33-38. 